\title{
Complex connectives*
}

\author{
Sarah E. Murray \\ Cornell University
}

\begin{abstract}
This paper discusses the interpretation and analysis of several sentential connectives found in Cheyenne (Algonquian), drawing on the author's fieldwork as well as several collections of texts. Coordinating connectives in English, including and, but, and or, are monomorphemic. In Cheyenne, the basic form used for conjunction is naa. Other connectives are morphologically complex, formed by combining naa with additional morphemes, all of which have independent uses. These complex connectives, and certain uses of naa alone, are challenges for a compositional, truth-functional analysis. In particular, though disjunction is logically weaker than conjunction, two forms for disjunction - naa mátó=héva and naa mó=héá'e - each contain the conjunction naa. Several recent analyses of similar data argue the basic element is not true conjunction. However, the data in these languages differ from Cheyenne in crucial ways. Building on these analyses, and other work on the semantics of disjunction, this paper proposes an analysis of the Cheyenne connectives that preserves naa as conjunction. Specifically, naa is analyzed as dynamic conjunction, and different from English and in important ways.
\end{abstract}

Keywords: Conjunction, disjunction, Cheyenne, Algonquian, semantic fieldwork

\section{Introduction}

Coordinating sentential connectives in English include and, but, and or. Though these connectives can have other uses, the focus here is where they join two complete sentences, as in English (1) - (3).

Annie danced and Shelly sang.

(2) Annie danced but Shelly sang.

* I would like to thank my Cheyenne consultants, and others I have talked with about Cheyenne, for their collaboration and discussion of the Cheyenne language. I would also like to thank Chris Barker, Maria Bittner, Adam Bjorndahl, Wayne Leman, Lisa Matthewson, Mats Rooth, Todd Snider, William Starr, Matthew Stone, the Cornell Semantics Group, the SALT editors, especially Jacob Collard, and audiences at SALT 27 at Maryland, the 2015 TbiLLC Symposium, SULA 8 at UBC, the 45th Algonquian Conference at Ottawa, UC Berkeley, UT Austin, New York University, Stanford University, and Wayne State University for helpful comments and discussion. Any errors are my own.

C2017 Murray 
Annie danced or Shelly sang.

The standard analysis of these connectives is truth-functional, a function of the truth values of their parts, as in the truth tables given in Figure 1.

\begin{tabular}{c|c|cc|c|c}
$\mathrm{P}$ & $\mathrm{P} \wedge \mathrm{Q}$ & $\mathrm{Q}$ & $\mathrm{P}$ & $\mathrm{P} \vee \mathrm{Q}$ & $\mathrm{Q}$ \\
\hline \hline $\mathrm{T}$ & $\mathrm{T}$ & $\mathrm{T}$ & $\mathrm{T}$ & $\mathrm{T}$ & $\mathrm{T}$ \\
$\mathrm{T}$ & $\mathbf{F}$ & $\mathrm{F}$ & $\mathrm{T}$ & $\mathbf{T}$ & $\mathrm{F}$ \\
$\mathrm{F}$ & $\mathbf{F}$ & $\mathrm{T}$ & $\mathrm{F}$ & $\mathbf{T}$ & $\mathrm{T}$ \\
$\mathrm{F}$ & $\mathrm{F}$ & $\mathrm{F}$ & $\mathrm{F}$ & $\mathrm{F}$ & $\mathrm{F}$
\end{tabular}

Figure 1 Truth tables for conjunction $\wedge$ and disjunction $\vee$

Under these definitions, conjunction is logically stronger than disjunction: $P \wedge Q$ is true in strictly fewer cases than $P \vee Q$ (see bold in Figure 1). The disjunction is true when the conjunction is true, but not vice versa. The adversative, or contrastive, conjunction but is typically analyzed with the same truth table as conjunction, with an added contribution of contrast (though the status of this contrastive contribution is debated, e.g., Frege 1892; Lakoff 1971; Grice 1961, 1975, Winter \& Rimon 1994; Bach 1999; Potts 2005). Even if these analyses work for English and, or, and but, not all languages have connectives that map so neatly to these analyses. This paper discusses such a case, where the connectives are morphologically complex - containing the basic form for conjunction. Can you build disjunction from conjunction?

This paper concentrates on the sentential connectives found in Cheyenne, an Algonquian language spoken in Montana and Oklahoma. ${ }^{1}$ In Cheyenne, the connective used for conjunction is $n a a$, as in (4). ${ }^{2}$

$$
\begin{aligned}
& \text { Annie é-ho'soo'e naa Shelly é-néméne. } \\
& \text { Annie 3-dance CONN Shelly 3-sing } \\
& \text { 'Annie danced and Shelly sang.' }
\end{aligned}
$$

1 The Cheyenne data presented in this paper draws on the author's fieldwork in Montana every summer since 2006, which builds on a grammar (Leman 2011), collections of texts (Leman 1980a, 1987), and a dictionary (Fisher, Leman, Pine \& Sanchez 2006). Examples are from fieldwork unless otherwise cited. For all examples, the morphological analysis, glossing, and translation are my own.

2 Cheyenne orthography and glossing conventions: $\mathbf{V}$ high pitch vowel, $\overline{\mathrm{V}}$ mid pitch vowel, $\dot{\mathrm{V}}$ voiceless vowel (all final vowels are voiceless, but not marked), ' [1], š [f]; 1 first person, 2 second person, 3 third person, AN animate, CONN connective, CND conditional, CNJ conjunct (dependent) clause, CNTR contrastive, DEL.IMP delayed imperative, DIR direct voice, EXCL exclusive, FUT future, HAB habitual, HYP hypothetical conjunct mode, IM.IMP immediate imperative, INAN inanimate, IND indicative conjunct mode, NEG negation agreement suffix, PL plural, PROS prospective, PSV passive, Q interrogative proclitic, PURP purposive, TRL translocative (away from speaker). 
Complex connectives

Other sentential connectives are morphologically complex, as in (5) - (7), formed from naa combined with other particles (see also Murray 2017).

Annie é-ho'soo'e naa máto Shelly é-ho'soo'e.

Annie 3-dance CONN also Shelly 3-dance

'Annie danced and also Shelly danced.'

(6) Annie é-ho'soo'e naa oha Shelly é-sáa-ho'sóé-he.

Annie 3-dance CONN CNTR Shelly 3-not-dance-NEG ${ }_{\mathrm{AN}}$

'Annie danced but Shelly didn't dance.'

(7) Annie é-ho'soo'e naa mátò=héva Shelly é-néméne.

Annie 3-dance CONN also=héva Shelly 3-sing

'Annie danced or Shelly sang.'

(Murray 2017: 154)

These connectives pose a challenge for a compositional, truth-functional analysis: since they are morphologically complex, what (unique) meanings can be assigned to naa and to the particles it combines with to achieve the meanings of the connectives? In particular, all of the complex connectives contain naa, including the disjunction naa mátó=héva, illustrated in (7). Since disjunction is logically weaker than conjunction, what kind of meaning can we give to naa?

There are four possibilities for analyzing naa: as ambiguous between a conjunctive and disjunctive interpretation, as underspecified between them, as just disjunction, or as just conjunction. Recently, several authors have proposed analyses of related data from other languages, arguing the basic element is not true conjunction. Davidson 2013 argues for an underspecification analysis of the general use coordinator in American Sign Language. Bowler 2014 analyses a similar coordinating element in Walpiri as disjunction. However, the data in these languages differ from Cheyenne in crucial ways. Building on these analyses, and other work on the semantics of disjunction (e.g., Zimmerman 2000), this paper proposes an analysis of the Cheyenne connectives that preserves naa as conjunction.

The connective system of Cheyenne is discussed in Section 2, including other uses of the particles that form the complex connectives. Section 3 discusses the Davidson 2013 underspecification analysis of an American Sign Language coordinator and the potential of applying it to the Cheyenne system. Section 4 discusses the Bowler 2014 analyses of a Walpiri coordinator as disjunction and why it is incompatible with the Cheyenne data. Section 5 proposes an analysis of the Cheyenne connectives that maintains naa as conjunction. Specifically, naa is analyzed as dynamic conjunction, different from English and in several ways. Section 6 is the conclusion and discussion of related patterns. 


\section{The Cheyenne connective system}

Cheyenne is an indigenous language from the Algonquian language family, currently spoken in Montana and Oklahoma. It's an endangered language, with most of the fluent speakers being older adults. Several language revitalization efforts are in progress, including language classes at the local schools and tribal college, as well as efforts for young children.

The basic sentential connective in Cheyenne in naa, illustrated in (4) above and (8) below. As in (8), sentences are often just complex, inflected verbs, as Cheyenne is polysynthetic (see Leman 2011 and the grammar overview in Murray 2010).

$$
\begin{aligned}
& \text { É-vó'ome-vovó'háse naa é-möšéškanahe. (Leman 1980a:72) } \\
& \text { 3-white-be.spotted CONN } \\
& \text { 'It (a pinto) was white-spotted and (it was) brown.' }
\end{aligned}
$$

It can also be used to conjoin other categories, such as names, and in texts it is frequently used at the beginning of sentences (see Murray 2017).

$\mathrm{Na}$ can co-occur with a wide range of particles, including the additive particle máto, as in (5) above and (9) below. Alone, máto is interpreted similar to English also, as illustrated in (10), from a story about Cheyenne beliefs.

(9) Ná-to'se-ée-ho'soo'e naa máto ná-to'se-néméne. (Leman 2011:207) 1-PROS-around-dance CONN also 1-PROS-sing

'I'm going to dance around and also I'm going to sing.'

$$
\begin{array}{ll}
\text { É-ohke-éve-e'h-e-o'o } & \text { máto vékèséhe-mèstae-o'o. } \\
\text { 3-HAB-about-fear-PSV-3PL also bird-spook-3PL }
\end{array}
$$

'Owls are also feared.'

(Leman 1987:214)

Adversative conjunctions are formed with naa and the particle oha, as in (6) above and (11) below. Oha can occur without naa, contributing an exclusive meaning similar to English only or except, as in (12) and (13).

Annie é-ho'soo'e naa oha Shelly é-sáa-ho'sóé-he. =(6) Annie 3-dance CONN CNTR Shelly 3-not-dance-NEG $\mathrm{AN}_{\mathrm{AN}}$ 'Annie danced but Shelly didn't dance.'

(12) Oha ná-tsèhésenèstsé-táno.

(Fisher et al. 2006: oha) CNTR 1-talk.Cheyenne-want 'I want to speak only Cheyenne.' 
Complex connectives
Naa hétsetseha oha no'ka ná-ta-évảho'eōhtse. (Leman 1987:17) CONN now
CNTR one.time 1-TRL-back-arrive

'And now I've only been there once.'

In (13), naa occurs in addition to oha, but they are not adjacent, and do not form an adversative conjunction. Naa occurs at the beginning of the sentence in (13), as is frequent in texts, separated from oha by hétsetseha 'now'. The adversative conjunction interpretation "but now I've been there once" is not possible - the oha 'only' associates with the speaker's being in a place one time (only).

Like for English but, the contrast indicated by naa oha can be made explicit, as in (14).

$$
\begin{aligned}
& \text { Màhtohto ka'èškóneh-o é-tà-hé-ho'sóe-o'o naa oha Annie } \\
& \text { ten child-PL 3-TRL-PURP-dance-PL CONN CNTR Annie } \\
& \text { é-no'kè-ho'soo'e. } \\
& \text { (Murray 2017: 154-5) } \\
& \text { 3-one-dance } \\
& \text { 'Ten children went to dance but Annie was the only one who danced.' }
\end{aligned}
$$

In (14), the first conjunct states that there were ten children who went with the purpose of dancing. The second conjunct presents contrasting information: counter to this intent, of the ten children, only Annie danced. ${ }^{3}$ In such examples, the use of naa alone - without some indicator of contrast - is infelicitous, given in (15).

$$
\begin{aligned}
& \begin{array}{lll}
\text { \# Màhtohto ka'ěškóneh-o é-tả-hé-ho'sóe-o'o } & \text { naa Annie } \\
\text { ten } & \text { child-PL } & \text { 3-TRL-PURP-dance-PL CONN Annie } \\
\text { é-no'kè-ho'soo'e. } & \text { (Murray 2017: 155) } \\
\text { 3-one-dance } &
\end{array} \\
& \text { \# 'Ten children went to dance and Annie was the only one who danced.' }
\end{aligned}
$$

In other cases, such as (11), the oha is optional; whether or not it should be used depends on the context. This is parallel to the distribution of English and and but: both (16) and (17) are possible, but in different contexts.

(17) Annie danced but Shelly didn't dance.

As with English but, it seems appropriate to analyze Cheyenne naa oha as conjunction with an added contrastive contribution, but with the contrastive contribution

3 The 'only' meaning in the second conjunct is contributed by the prefix $n o$ ' $k \dot{e}$ - 'one/alone' in the final verb, cf. 'only one' in the translation of (14), or, alternatively, 'Annie alone danced'. 
coming from from a separate lexical item, oha. Additional combinations, such as naa nèhe'še 'and then', are discussed in Murray 2017.

So far, both complex connectives above and the uses of naa alone are compatible with analyzing naa as conjunction. The main challenge comes from disjunction: if naa is analyzed as conjunction, how can that compositionally contribute to disjunction, which is logically weaker?

There are at least two ways of expressing disjunction in Cheyenne. The first, illustrated above in (7) and below in (20), is naa mátó=héva. The particles máto and héva can each occur on their own. An example of máto alone is given above in (10) - it is an additive particle, similar to English also. The particle héva has uses similar to English perhaps or maybe, as in (18). It also has uses closer to English about and like, as illustrated in (19), from a story about how men and women should behave when married.

(18) [Context: The narrator is talking about possible good things that could come to their people.]

Héva nả-htse-vésè-háa'éše-vo'èstanéhévé-me.

(Leman 1987:211)

héva 1-FUT-also-long.time-live-1PL.EXCL

'Perhaps we will live a long time.'

(19) [Context: A young man respects his in-laws. He doesn't talk to his mother-in-law. He can talk to his father-in-law, but he respects him.]

Héva é-to'sè-sáa-havèsévo'anē-he.

(Leman 1980a:81)

héva 3-PROS-not-talk.bad-NEG ${ }_{\mathrm{AN}}$

'Like he won't talk bad.'

Combined, naa, máto, and héva form the disjunction naa mátó=héva, as in (20).

$$
\begin{aligned}
& \text { É-ohke-péen-ē-nèstse naa mátö=héva } \\
& \text { 3-HAB-grind-PSV-PL.INAN CONN also=héva } \\
& \text { é-ohke-pénöh-é-nèstse. } \\
& \text { 3-HAB-pound-PSV-PL.INAN }
\end{aligned}
$$

'They (chokecherries) are ground or they are pounded.' (Leman 1980a:77)

Importantly, in (20) máto and héva are pronounced together, as mátó=héva, which is three syllables. ${ }^{4}$ When pronounced separately, máto and héva are each two syllables.

4 The sequence $t \dot{o}=h e ́$ in mátó=héva forms a single, complex syllable. A complex syllable is one of the form $\mathrm{CV}_{1} \mathrm{hV}_{2}$, which is pronounced as $\mathrm{C}^{\mathrm{h}} \mathrm{V}_{1}+\mathrm{V}_{2}$ (Leman 2011). That is, the first consonant becomes aspirated and the two vowels coalesce. 
Complex connectives

There are sequences of the words naa, máto, and héva that do not form a disjunction; see Murray 2017.

Another way to express disjunction in Cheyenne combines naa with the question particle móhe and the epistemic particle hēāe (sometimes written héáe). ${ }^{5}$ The question particle móhe alone can be translated as 'really?' or 'right?'. It often cliticizes onto the following word, as in (21). The particle $h \bar{e} \bar{a}^{\prime} e$ alone is similar to English maybe, as in (22) and (23).

Mó=né-naóotse?

(Fisher et al. 2006: móhe)

$\mathrm{Q}=2$-sleep

'Are you sleeping?'

(22) Hēā'e é-naóotse.

(Fisher et al. 2006: hēéa'e) maybe 3-sleep

'Maybe he's sleeping.'

(23) [Context: The speaker is talking about a woman he went to see.]

Hēā'e né-héne'enōv-o Kèhaéné'e.

(Leman 1987:174)

maybe 2-know.s.o-DIR Squint.Eye.Woman

'Maybe you know Squint Eye Woman.'

Examples (24) and (25) below are disjunctions formed by combining these two particles with naa.

(24) [Context: The narrator is discussing what lessons we might learn from a story, how different people were treated.]

... hēā'e né=hé'e naa mó=héá'e né=hetane ...

maybe that=woman $\operatorname{CONN} Q=$ maybe that=man

'...maybe that woman or that man...'

(Leman 1987:251)

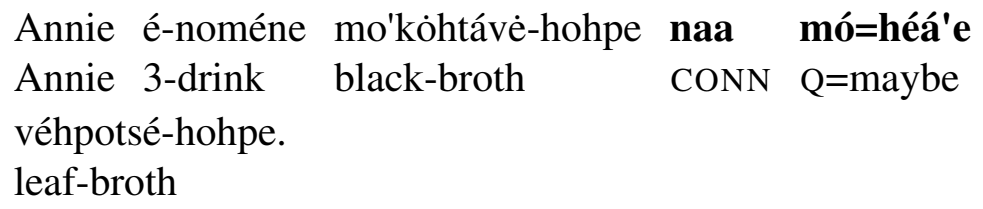

'Annie drank coffee or tea.'

(Murray 2017: 158)

5 Both héva and hēē'e may be epistemic particles, but hēe' $e$ seems much closer to English 'maybe', while héva has a wider range of uses. For example, héva is much more common in texts (114 occurrences in Leman 1980a (62 texts, 92 pages) compared to 5 for $h \bar{e} \bar{a}^{\prime} e$ ). In addition to the uses discussed above, héva can be a hedge or filler particle and can actually be a part of several grammatical constructions (see Murray 2017). 
These two different ways of expressing disjunction combine various particles with naa. This seems like a compositional process in Cheyenne, with other possibilities as well, including (26), which incorporates a fourth particle.

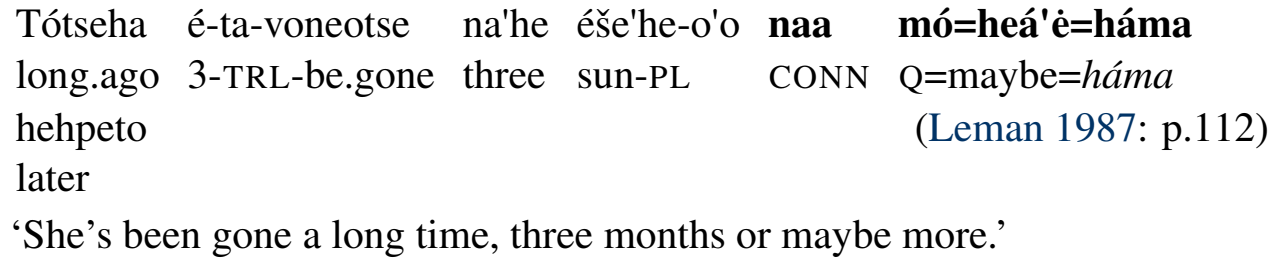

The system of particles in Cheyenne has never been studied in depth, and that is not the goal of the current paper. The main question here is: can naa still be analyzed as conjunction in these constructions? In Section 5 I argue yes, but first consider other possible analyses in Sections 3 and 4.

There is one last way of expressing disjunction in Cheyenne - in certain grammatical contexts, with naa alone, as in (27).

(27) [Context: The speaker is asked to pass a cup, but he's not sure which cup was intended.]

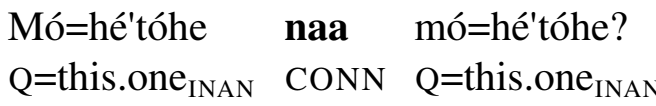

(Murray 2017: 158)

'Do you mean this one (pointing) or this one (pointing)?'

Cheyenne (27) is interpreted as an alternative question: possible answers include 'that one (pointing)' but not 'yes' or 'no'. It is important to highlight that (27) has two interrogative proclitics, and so syntactically naa conjoins two interrogatives. The interrogative proclitics in (27) are on demonstratives, but the same construction is possible with complete sentences (see Murray 2017).

Recognizing (27) as containing two interrogatives, another possible translation would be just two interrogatives in sequence, as in (28). A translation with 'and', (29), is not representative of the meaning of Cheyenne (27).

(28) Do you mean this one (pointing)? Do you mean this one (pointing)?

(29) Do you mean this one (pointing) and (do you mean) this one (pointing)?

So, does (27) mean naa must be analyzed as disjunction? I argue in Section 5 that this use of naa can actually be analyzed as conjunction, though not equivalent to English (29). In addition, this use of naa appears to be limited to interrogatives disjunctive interpretations are not generally available for naa alone, as discussed in Section 3 below. 
Complex connectives

\section{$3 \quad$ Naa as underspecified or ambiguous?}

American Sign Language (ASL) has a coordinator (COORD) that can be interpreted as either conjunction or disjunction, depending on various factors (Davidson 2013). For example, in different contexts the same sentence (IX Mary DRINK TEA coord COFFEE) can be interpreted disjunctively (30a) or conjunctively (30b).

a. [Context: I know that everyone had exactly one drink at the party. I wonder what Mary chose to drink at the party, and ask my friend. She replies:]

IX Mary DRINK TEA coord COFFEE. 'She (Mary) drank tea or coffee.'

b. [Context: I see that Mary looks very caffeinated and sick! I wonder how much caffeine she may have had, and ask my friend. She replies:] IX Mary DRINK TEA coord COFFEE!

'She (Mary) drank tea and coffee!'

The difference interpretations of COORD can be conditioned by context of utterance, as in (30), or by prosodic cues or other lexical elements. Davidson 2013 argues convincingly against a lexical ambiguity approach to this connective. Instead, Davidson 2013 proposes an underspecification analysis - COORD is set union, as in (31) for one of the two variants of the coordinator.

$$
\llbracket A \text { COORD-SHIFT } B \rrbracket=\llbracket A \rrbracket \cup \llbracket B \rrbracket
$$

(Davidson 2013: 18)

The result of coordination is a set of propositions, which is either universally or existentially quantified over, yielding a conjunctive or a disjunctive interpretation respectively. Either all of the propositions in the set are true (conjunction) or at least one of them is (disjunction). ${ }^{6}$ Crucially, this universal or existential quantification comes from an operator outside the coordination - these operators are licensed by semantic environment, context of utterance, non-manual marking, or focus particles.

This underspecification analysis elegantly captures the ASL data, where the addition of other elements can specify either a conjunctive or disjunctive interpretation, and where either interpretation is possible in different contexts. However, the facts in Cheyenne are different: sentences with naa cannot generally have a

6 This analysis builds on other work in alternative semantics, including Alonso-Ovalle 2006 on disjunction (see also Kratzer \& Shimoyama 2002; Simons 2005a,b; AnderBois 2011, among others). Winter 1995 has a similar analysis of conjunction, arguing conjunctive morphemes like and just form tuples and lack any additional meaning contribution, though disjunction is treated as Boolean. 
disjunctive interpretation, and do not need extra specification to have a conjunctive interpretation. Consider Cheyenne (32) and (33), based on ASL (30a) and (30b).

(32) [Context: I know that everyone had exactly one drink at the party. I wonder what Annie chose to drink at the party, and ask my friend. She replies:]

\# É-noméne mo'kỏhtávè-hohpe naa véhpotsé-hohpe.

3-drink black-broth CONN leaf-broth

\# 'She drank coffee and tea.'

Cheyenne (32) is infelicitous: the context allows only a disjunctive interpretation, which is not possible for naa. The intended meaning 'She drank coffee or tea' is not available. Instead, naa is interpreted as conjunction, clashing with the context. If naa were a general use coordinator, this parallel of (30a) should be felicitous.

Example (33) below shows the Cheyenne parallel of ASL (30b), which is felicitous. This context sets up a conjunctive interpretation, which is available.

(33) [Context: I see that Annie looks very caffeinated and sick! I wonder how much caffeine she may have had and ask my friend. She replies:]

É-noméne mo'köhtávè-hohpe naa véhpotsé-hohpe.

3-drink black-broth CONN leaf-broth

'She drank coffee and tea.'

In both (32) and (33), naa is interpreted as conjunction, regardless of the context. These facts are crucially different from ASL, and so the Davidson 2013 analysis that so well captured the ASL data doesn't seem appropriate. Could naa still be argued to be underspecified? Since naa doesn't need any external contribution for a conjunctive interpretation, we would have to assume a null universal operator that occurs with naa in all and only its conjunctive interpretations. This is not explanatory, and does not seem in the spirit of Davidson 2013, where the universal or existential operators are licensed by elements of the sentence or context.

If not underspecified, what about ambiguous? As mentioned above, Davidson 2013 argues convincingly against an ambiguity analysis of COORD in ASL. Similar arguments hold for Cheyenne. Simply saying there are two lexical items naa, one expressing conjunction and one expressing disjunction, is not explanatory. Further, the disjunctive naa and the conjunctive naa would have complementary environments - they never occur in the same context. In Cheyenne there is no truly ambiguous string: naa alone means conjunction in most cases, and expresses disjunction as part of a complex connective. Ideally, an analysis of the Cheyenne connectives would account for this distribution and the relation between the parts of the complex connectives and their independent uses. Minimally, a unified analysis of naa across all of these constructions would be desirable, if possible. 
Complex connectives

\section{$4 \quad N a a$ as disjunction?}

Another possible analysis of Cheyenne naa is as disjunction, since a disjunctive meaning would be true in conjunctive scenarios. This is the proposal of Bowler 2014 for Warlpiri coordinator manu. In unembedded contexts, manu has a conjunctive interpretation, as in (34a); Bowler 2014 says that unembedded manu cannot be interpreted disjunctively.

a. Cecilia manu Gloria=pala yanu tawunu-kurra.

Cecilia manu Gloria=3DU.SUBJ go.PST town-ALL

Jirrama $=$ juku.

two=exactly

'Cecilia and Gloria went to town. Exactly two did.'

b. Gloria marda, Cecilia marda yanu tawunu-kurra=ju.

Gloria maybe Cecilia maybe go.PST town-ALL=TOP

'Gloria or Cecilia went to town.'

(lit. 'Maybe Gloria, maybe Cecilia went to town.')

To express disjunction, constructions like (34b) are used: two instances of the epistemic modal marda with a covert manu operator. ${ }^{7}$

Despite the conjunctive interpretation in unembedded environments, Bowler 2014 analyzes manu as disjunction (35) and argues Warlpiri lacks a conjunctive coordinator parallel to English and.

$$
\llbracket \mathrm{manu} \rrbracket^{w}=\llbracket \mathrm{or}_{\text {English }} \rrbracket^{w}=\lambda \mathrm{t}_{1} \in \mathrm{D}_{t} \cdot \lambda \mathrm{t}_{2} \in \mathrm{D}_{t} \cdot \mathrm{t}_{1}=1 \vee \mathrm{t}_{2}=1
$$

(Bowler 2014: 141)

On this analysis, because there is no stronger lexical item parallel to English and, there are no exclusivity implicatures generated by the use of the disjunction. Bowler 2014 proposes that the disjunctive meaning of manu can be seen in embedded environments, and that when unembedded, the meaning gets strengthened to conjunction by recursive exhaustification via an optional, null operator present in the syntactic

7 Bowler 2014 does not discuss this construction except to say that it is interpreted as a conjunction of two epistemic possibilities with a covert manu, with $\llbracket$ marda $\rrbracket^{w}=\llbracket$ maybe $_{\text {English }} \rrbracket^{w}$. However, since manu is analyzed as disjunction, it seems this would be interpreted as a disjunction of epistemic possibilities - truth conditions that are too weak, at least for the similar Cheyenne constructions, e.g., (24). Matthewson 2014 has a different analysis of similar constructions St'át'imcets and Tlingit, as conjunctions of epistemic possibilies following Zimmerman 2000, which is discussed in Section 5. 
structure (see also Singh, Wexler, Astle-Rahim, Kamawar \& Fox 2016 for children's acquisition of English).

The embedded environments that Bowler 2014 considers are under negation, in the antecedent of a conditional, and in Wh-questions; manu is reported to be interpreted as disjunction under negation and ambiguous in conditionals and questions. For example, take the negated Warlpiri sentence in (36).

Warlpiri

Cecilia manu Gloria kula=pala

Cecilia manu Gloria NEG=3DU.SUBJ

(Bowler 2014: 139)

'Neither Cecilia nor Gloria went to Lajamanu. Neither one.'

Bowler 2014 reports that examples like (36) are compatible with the 'neither' reading $(\neg P \wedge \neg Q)$ and concludes that manu is interpreted disjunctively, i.e., as disjunction under negation, assuming DeMorgan's law $\neg(P \vee Q) \Leftrightarrow(\neg P \wedge \neg Q)$. Further evidence reported is that such examples cannot be interpreted as conjunction under negation: "speakers are uncomfortable using $P$ manu $Q$ under negation in contexts in which they consider it possible that only one of $\{\mathrm{P}, \mathrm{Q}\}$ is false" (Bowler 2014: 139). This is one of the primary arguments for treating manu as disjunction: in this embedded environment, only the disjunctive interpretation is possible.

However, the interaction of negation with conjunction and disjunction is not so straightforward crosslinguistically. Szabolsci \& Haddican 2004 show that in many languages "negated definite conjunctions are naturally and exclusively interpreted as "neither"'. Szabolsci \& Haddican 2004 look in depth at Hungarian, in contrast to English; both the negated disjunction and the negated conjunction have different interpretations across languages. Compare the negated English conjunction in (37) to the negated Hungarian conjunction in (38).

(37) Mary didn't take hockey and algebra. (Szabolsci \& Haddican 2004: 219) can mean 'Mary didn't take hockey or didn't take algebra'

Hungarian

(Szabolsci \& Haddican 2004: 220)

Mari nem járt hokira és algebrára.

Mari not went hockey-to and algebra-to

cannot mean 'Mary didn't take hockey or didn't take algebra'

can mean 'Mary didn't take hockey and didn't take algebra'

The negated conjunction in (38) is interpreted as 'neither', like the Warlpiri data in (36). However, this crosslinguistic pattern does not lead Szabolsci \& Haddican 2004 
to argue connectives like Hungarian és are not conjunction, or that the conjunction scopes over the negation, but instead that conjunctions in such languages are like plurals and undergo "homogeneous distributive predication within the scope of negation" (Szabolsci \& Haddican 2004: 225).

Because of this, it is difficult to make an argument for a disjunctive analysis based on negated conjunctions like (36). Cheyenne negated conjunctions also have the 'neither' interpretation, like Warlpiri (36) and Hungarian (38), as well as ASL (Davidson 2013: 25-6), but there are several possible explanations. In addition, because of the morphosyntax of negation in Cheyenne, in many cases the conjunction clearly scopes over negation (see, e.g., (6)).

Bowler 2014 discusses two other embedded environments: antecedents of conditionals and Wh-questions. In both of these environments, Bowler 2014 reports the Warlpiri coordinator manu is ambiguous between conjunction and disjunction, based on consultant's translations.

The Cheyenne connective naa has a crucially different distribution. First, the disjunction constructions are not just two modals, but more complex constructions including naa and other discourse particles (see Section 2, e.g., (20)). Second, the disjunctive interpretation is not available for naa alone when embedded in conditional antecedents, as shown in (39).

\begin{tabular}{|c|c|c|}
\hline *Màh-vé'-héstähe-to & Mo'òhtávỏheomenéno & naa \\
\hline HYP-CND-be.from-CNJ.2SG & Lame.Deer & CONN \\
\hline $\begin{array}{ll}\text { Oévemanähéno, } & \text { ho'soo'è-stse } \\
\text { Birney } & \text { dance-IM.IN }\end{array}$ & $\begin{array}{l}\text { e! } \\
\text { MP.2SG }\end{array}$ & \\
\hline
\end{tabular}

Cheyenne naa cannot be interpreted as disjunction in (39); a conjunctive interpretation is not available either, since one cannot be from two different places. The argument for a disjunction analysis rests on the availability of a disjunctive interpretation in embedded environments. Since this interpretation is not available in Cheyenne, a disjunction analysis is not well-suited to the connective naa.

Davidson 2013 also argues against this possible analysis for ASL, with the argument based on analyses of modals with seemingly variable quantificational force in St'at'imcets (Rullmann, Matthewson \& Davis 2005) and in Nez Perce (Deal 2011). Deal 2011, for example, discusses the Nez Perce modal o'qa, which can express either possibility or necessity. Deal 2011 analyses o'qa as having existential force - compatible with both interpretations, since necessity entails possibility. Evidence for this comes from embedded environments where the entailment scale is reversed, such as in antecedents of conditionals and in the scope of negation. The 
modal o'qa has only the existential interpretation in such contexts.

Similarly, disjunction and conjunction form a scale, with conjunction entailing disjunction. A construction that can express both conjunction and disjunction could be analyzed as disjunction, which, in unembedded environments, would be compatible with either interpretation. But we would expect to see only disjunctive interpretations in scale-reversing contexts. Davidson 2013 argues this is not the case for ASL, and as seen above in (39), this is not the case for Cheyenne.

\section{$5 \quad N a a$ as conjunction}

In the above two sections, I have explored the logical space of analyses for naa: as underspecified between conjunction and disjunction, as ambiguous, and as disjunction, ultimately concluding that none of these possibilities is suited to the Cheyenne connective. This section proposes to analyze naa as conjunction. A summary of the data to be accounted for is given in (40).

Distribution of Cheyenne naa

i. $\quad n a a$ alone as conjunction, e.g., (8)

ii. naa at beginning of sentences in texts (Murray 2017)

iii. $\quad$ naa as part of additive conjunction naa máto (9)

iv. naa as part of contrastive conjunction naa oha, e.g., (11)

v. naa between interrogatives (27)

vi. naa as part of the complex disjunctions, e.g., (20) and (24)

The biggest challenge for analyzing naa as conjunction comes from the disjunctions (40vi), which I discuss at the end of this section.

The primary feature of a conjunction analysis is it straightforwardly captures the lack of variation in interpretation of naa alone (40i), as well as naa as part of complex conjunctions (40iii) and (40iv). Consider the contrastive conjunction: as with English but, it seems appropriate to analyze Cheyenne naa oha as conjunction with an added contrastive contribution. Unlike English but, the contrastive contribution of naa oha comes from a separate lexical item, oha, which can occur on its own with a related contrastive interpretation (see (12) above). ${ }^{8}$ I leave open the analysis of $o h a$, and the question of whether a unified analysis can be given for all of its uses. Nevertheless, it possible to maintain an analysis of naa as conjunction in this construction.

8 Crosslinguistically there is a connection between adversative connectives and contrast marking, exclusives (e.g., Malchukov 2004, Inoue 2007). In addition, only in English has an adversative use, e.g., Do what you like, only don't miss the train (Williams 1895). But in English this adversative use does not co-occur with the conjunction and: *Do what you like, and only don't miss the train. 
Complex connectives

Two other aspects of the distribution of naa are less straightforward: the frequent use of naa in texts, including at the beginning of sentences (40ii) and the use between interrogatives to form an alternative question (40v). Both of these uses of naa can be analyzed as conjunction if we take it to be dynamic conjunction. Dynamic conjunction is sequential update: the second conjunct is interpreted in a context updated by the first (e.g., Groenendijk \& Stokhof 1991). This relatively minimal contribution is typically used between sentences in a discourse. But it is this minimal nature of the contribution that allows dynamic conjunction to account for the uses of $n a a$ at the beginnings of sentences and between clauses other than declaratives, which is needed in general in Cheyenne, as well as in English (see, e.g., Starr 2016 and Murray \& Starr to appear). For Cheyenne, naa can occur between interrogatives, as seen above in (27), as well as between imperatives (41) and between a declarative and imperative (42), among other possible combinations.

$$
\begin{array}{lll}
\text { Néménè-stse } & \text { naa ho'sóe-o'o! } \\
\text { sing-IM.IMP.2SG } & \text { CONN } & \text { dance-DEL.IMP.2SG }
\end{array}
$$

(Murray 2016: 250)

'Sing (now) and dance (later)!'

$$
\begin{aligned}
& \text { Ná-to'se-néméne naa ho'sóe-o'o! } \\
& \text { 1-PROS-sing CONN dance-DEL.IMP.2SG } \\
& \text { 'I am going to sing and (you) dance (then)!' }
\end{aligned}
$$

Cases like these pose their own challenge to the standard analysis of conjunction and are support for the dynamic conception. But (41) and (42) are conjunctions - let's return to the case of naa between interrogatives discussed in Section 2, repeated in (43), where naa seems to be interpreted as disjunction.

(43) [Context: The speaker is asked to pass a cup, but he's not sure which cup was intended.]

$$
\text { Mó=hétóhe naa mó=hé'tóhe? }
$$

$\mathrm{Q}=$ this.one $_{\text {INAN }}$ CONN Q=this.one INAN $_{\text {. }}$

'Do you mean this one (pointing) or this one (pointing)?'

Cheyenne (43) is an alternative question (e.g., Romero \& Han 2003; Groenendijk \& Roelofsen 2009; Biezma \& Rawlins 2015, a.o.); answers include há'tóhe 'that one (pointing)' but not héehe'e 'yes' or hová'àháne 'no'.

So, is naa interpreted disjunctively in (43)? Going from the English translation, one might think so. However, just because we express this meaning in English with or does not mean any expression of this in another language will be a disjunction. Translation is of limited usefulness as a semantic fieldwork methodology: 
"Translations should always be treated as a clue rather than a result. An English translation of an object-language sentence does not provide direct evidence about the truth conditions of that sentence" (Matthewson 2004: 389). In fact, as discussed in Section 2, a translation of (43) as just a sequence of two interrogatives is possible, while a translation with and is not possible.

The naa in (43) can actually be analyzed as conjunction, under the dynamic analysis: sequential update of two interrogatives on a standard analysis of questions. Depending on your semantics for questions, in certain contexts a sequence of two interrogatives can produce an alternative question. For the purpose of illustration, I follow the semantics in Murray \& Starr to appear, which follows much of the literature on interrogatives: they are modeled as a set of propositions, or an update that introduces that set. In Figure 2 is an example diagram of the initial state $c_{0}$, which has four worlds: a world where both $A$ and $B$ are true $(A B)$, worlds where only one of the two propositions is true $(A b, a B)$, and a world where both propositions are false $(a b)$. The state $c_{0}$ is then updated with the interrogative ?A: $c_{0}[? A]$.

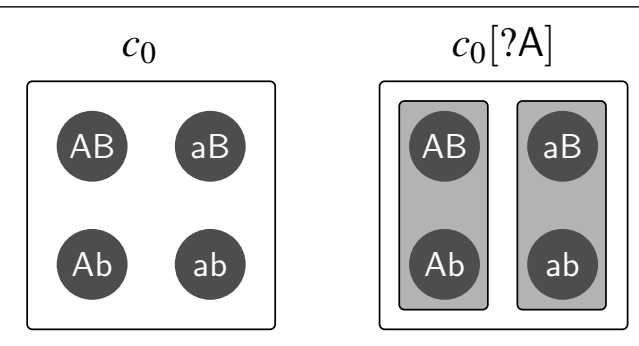

Figure 2 Initial state $c_{0}$ updated with ?A

The interrogative update ?A introduces the propositions that $A$ is true (here $\{A B, A b\}$ ) and that $A$ is false $\{a B, a b\})$; see Murray \& Starr to appear for details.

For analyzing Cheyenne (43), the alternative question, it's important to account for the prior context in that example, where the speaker was asked to pass a cup. The speaker is not sure which cup is meant, and so asks 'Do you mean this one (pointing) or this one (pointing)?'; I will represent the Cheyenne as ?A $\wedge$ ?B, which amounts to sequential update of $c[$ ?A] [?B]. Since the input context for this example already contains some information, I've eliminated a world from the initial state - the one where neither $A$ nor $B$ is true $(a b)$ - resulting in $c 1$ in Figure 3.

Figure 3 below shows the state $c_{1}$ is then updated with ?A, resulting in $c_{2}$, which is then updated with ?B. The interrogative update ?A introduces the propositions that $A$ is true (here $\{A B, A b\}$ ) and that $A$ is false $\{a B\}$ ); ?B introduces the propositions that $B$ is true (here $\{A B, a B\}$ ) and that $B$ is false $\{A b\}$ ). Essentially, we end up with the following set of propositions: $\{\{A B, A b\},\{a B\},\{A B, a B\},\{A b\}\}$. 
Complex connectives
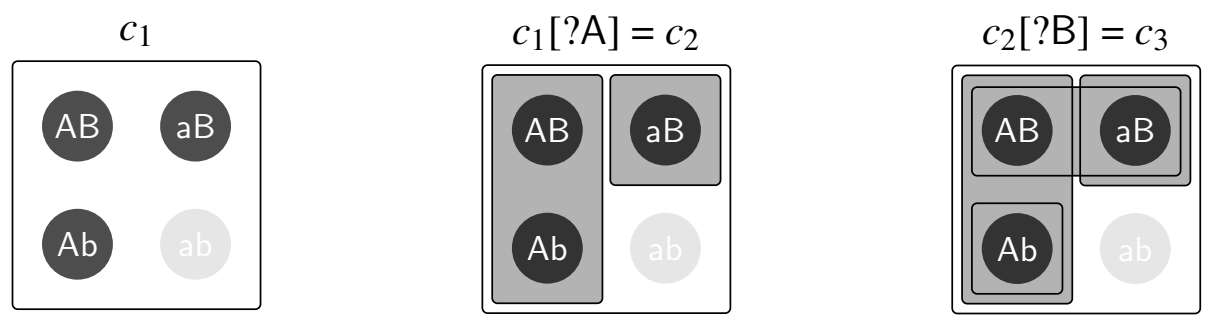

Figure 3 Sequential Interrogative Update for (43)

This does not represent a yes-no question, but an alternative question: the possible answers are that $A$ is true or that $B$ is true. In this example because the "neither" world (ab) has been excluded, via the prior context. One might go further and exclude the "both" world (AB), either through the context of this example, or through a presupposition that exactly one of the options (as in, e.g., Romero \& Han 2003).

Abstracting from the particulars, the idea is this: sequentially updating with two interrogatives in this case does not result in a yes-no question, but with a more complex set, which can be interpreted as an alternative question. The use of naa in (43) then is not a disjunctive use, but instead can be analyzed as dynamic conjunction. This builds on a general need to account for coordination across sentence types.

As discussed throughout this paper, the biggest challenge for a conjunction analysis of naa is its occurrence in the constructions expressing disjunction, (20), (24), (25), and (26) above. Since disjunction is logically weaker than conjunction, how do you add on to conjunction to build disjunction? One possibility is to weaken the conjuncts. In a way, this is what was done above for the interrogative case: a conjunction of interrogatives.

This type of analysis of disjunction was proposed in Zimmerman 2000 for free choice permission: disjunction as a conjunctive list of epistemic possibilities (see also Geurts 2005). On this analysis, sentences like (44) can be represented like (45).

$$
(\diamond p \wedge \diamond q)
$$

This analysis of disjunction has two key benefits: it is compatible with analyzing naa as conjunction and it reflects the morphology of the Cheyenne disjunctions, repeated here as (46) and (47), which each have a modal element. ${ }^{9}$ The analysis

9 Matthewson 2014 makes this point for similar constructions St'át'imcets and Tlingit: morphologically the constructions are lists/conjunctions of modals, matching the Zimmerman 2000 proposal. 
as a conjunction of epistemic possibilities seems particularly well suited to the naa $m o ́=h e ́ a ́ c e$ disjunctions, which contain the epistemic particle $h \bar{e} \bar{a}^{\prime} e$ and can have a modal on each conjunct, as in (47).

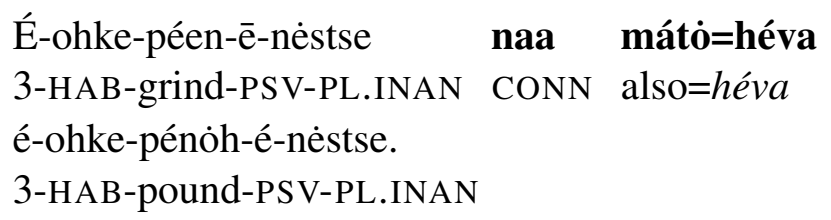

(47) [Context: The narrator is discussing what lessons we might learn from a story, how different people were treated.]

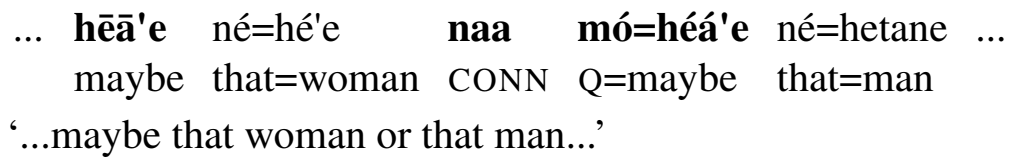

However, there are some challenges in adapting the Zimmerman 2000 analysis to the Cheyenne disjunctions. First, despite the morphological parallels, there are ways in which the Cheyenne morphology does not quite match the Zimmerman 2000 analysis. For naa mó=héá'e disjunctions, both instances of the modal hēáe are needed in some cases, but not in others, and seem to contribute to how likely one conjunct is over the other. For example, consider (48) as an answer to the question 'Where's Annie?'.

\section{É-hoo'e Sheridan naa mó=héá'e Billings. 3-be.at Sheridan CONN Q=maybe Billings 'She's in Sheridan or (maybe) Billings.'}

A Cheyenne consultant reported that from (48) it sounded more likely that Annie was in Sheridan, but still possible that she was in Billings. Disjunctions with only one overt modal, and how the modals contribute to the interpretation, would need to be accounted for. There are several other ways in which the morphology does not quite match the Zimmerman 2000 analysis. There is a question particle, móhe, as part of the naa mó=héá'e disjunctions. In the naa mátó=héva disjunctions, there is only one modal component, héva, and as discussed in Section 2, it has a wider range of uses than $h \bar{e} \bar{a}^{\prime} e$, and is not clearly epistemic (e.g., (46) and (54)). The naa mátó=héva disjunctions also include the additive particle máto.

The second challenge for adapting the Zimmerman 2000 analysis is that there are of course truth conditional and distributional differences in English between disjunctions and conjunctions of modal sentences, not to mention potential anaphoric 
Complex connectives

differences. With overt modals, modal subordination is required for subsequent anaphora (Roberts 1989; Stone 1999), as in (49).

(49) i. John might be eating a cheesesteak.

(Stone 1999: (12b))

ii. It $\{$ would be, \#is $\}$ very greasy.

As far as I know, there is no research into modal subordination with conjunctions of modal sentences, but a parallel of (49) with a conjunction would be (50).

(50) i. John might be eating a cheesesteak and Audrey might be eating a hamburger.

ii. It $\{$ ?would be, \#is $\}$ very greasy.

ii'. They $\{$ would be, \#are $\}$ very greasy.

Just as in (49), modal subordination is needed for anaphora with conjunctions of modal sentences. If disjunctions are interpreted as such, it seems to predict modal subordination would be needed for disjunctions as well.

External anaphora is possible for disjunctions, as in (51) with NPs and (52) with clauses, from Simons 1996.

(51) Either a soprano or an alto will sing. She will stand on that platform.

(Simons 1996: (20))

(52) For the final act, either a soprano will sing or an actress will perform a monologue. She will stand on that platform.

(Simons 1996: (35))

For these disjunctions, no modal subordination is necessary. One might wonder about the presence of "will" in the second sentences, but it is orthogonal to the issue of modal subordination. If these examples are given in the past tense, as in (53), this becomes clear.

(53) For the final act, either a soprano sang or an actress performed a monologue. She stood on that platform.

Whatever the explanation of why external anaphora is available with disjunction, it doesn't need modal subordination.

The same seems to be true for Cheyenne disjunctions, at least for the naa mátó=héva disjunctions, as in (54). Example (54) is from a text, and while it is suggestive, it is not ideal in proving this point: the disjunction is of numerals and there is a habitual marker ( $\mathrm{HAB})$, which is arguably quantificational and could facilitate the anaphora. 


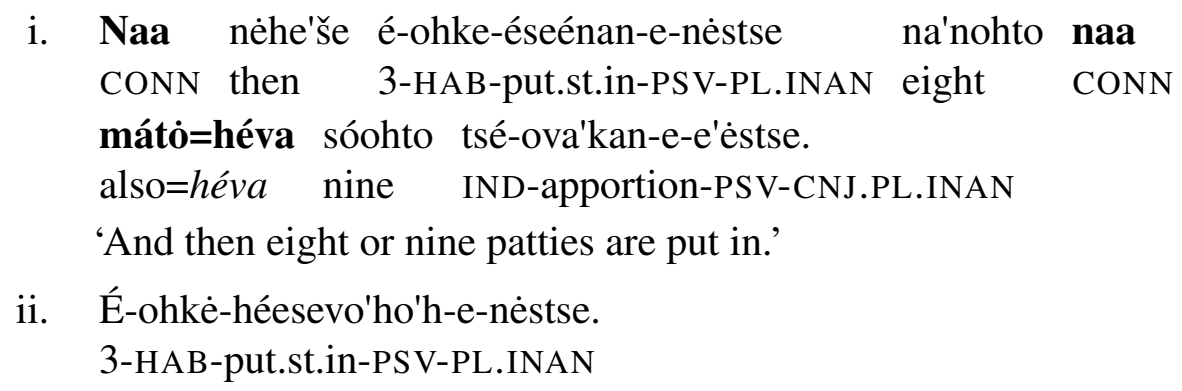

If there are differences in anaphoric potential between disjunctions and conjunctions of epistemic modals, this might be a useful diagnostic, but an example closer to (51) or (52) would be needed.

To sum up, analyzing disjunction as conjunction of epistemic possibilities is promising, at least for the naa mó=héá'e disjunctions. Most importantly for the purpose of this paper, it allows maintaining a conjunctive analysis of naa. Building disjunction from conjunction is possible by 'weakening' the conjuncts - in this case, to epistemic possibilities, and in the discussion of (43) above, to interrogative updates. As discussed above in this section, all of the other complex connective data is compatible with naa as conjunction, specifically as dynamic conjunction.

Dynamic conjunction, however, cannot be the whole story. Dynamic conjunction is just sequencing, the same as juxtaposition, which is not a sufficient model of English and. Take English (55) and (56) for example: adding and in (56) contributes an important change to the temporal sequencing of the two events.

Max fell; he slipped on a banana peel. $\quad$ (Bar-Lev \& Palacas 1980: 139)

(56) Max fell, and he slipped on a banana peel. (Bar-Lev \& Palacas 1980: 140)

Unlike in (56), in (55) we take Max's slipping on a banana peel as explanation of his falling, which leads to the temporal reversal; adding and removes this possible interpretation (Txurruka 2003). To prove this is not just a temporal restriction, Txurruka 2003 offers (57) and (58): the relation between sentences in (57) is still explanation, but not temporal; in (58), the explanation interpretation is not available.

(57) Mary and John baptized all their children. They are good Catholics.

(Txurruka 2003: 262)

(58) Mary and John baptized all their children and they are good Catholics.

(Txurruka 2003: 262) 
Complex connectives

In English, and adds constraints on the relations that can hold between sentence: "while sentence juxtaposition might be interpreted either as discourse coordination or subordination, and indicates coordination" (Txurruka 2003: 255; see also Txurruka 2000, Hobbs 1985; Lascarides \& Asher 1993; Asher \& Vieu 2005). It seems plausible to think that connectives in other languages might pose similar constraints. While Cheyenne naa seems less constrained than English and, a thorough investigation of the kinds of discourse relations that can hold with naa is called for.

A dynamic conjunction analysis also does not account for the anaphoric potential of connectives, both in what anaphora they allow to their parts and anaphora to the conjunction or disjunction itself. Anaphora is possible to both conjunctions and disjunctions, as in (59) and (60), where that can refer to the conjunction in (59) and in (60) the disjunction (see also Snider 2017).

(59) Annie danced and Shelly sang. Dale told me that.

(60) Annie danced or Shelly sang. Dale told me that.

Just as nominal conjunction forms a complex individual discourse referent which can be referred to later by a plural anaphor, sentential coordination forms a complex propositional discourse referent. In (60), Dale told the speaker the disjunction - not just one of its parts. These anaphoric properties, and the constraints on discourse relations, should ultimately be part of the analysis of the connectives.

\section{Conclusions and discussion}

The primary goal of this paper is to maintain an analysis of the Cheyenne connective naa as conjunction. In Cheyenne, the connectives are morphologically complex, built off naa. As seen in Sections 3 and 4, analyses of connectives in other languages with similar patterns were not well-suited to the Cheyenne system. However, analyzing naa as conjunction leads to compositionality questions, especially for the disjunctions, since conjunction is logically stronger than disjunction, and for connectives between different kinds of clauses.

The proposed solution (Section 5) was to follow the dynamic conception of conjunction, as sequencing. This allows a general analysis of naa in all of the complex connectives, between a range of clause types, and makes sense of the use of naa in texts, while maintaining the benefits of a classical conjunction analysis. A possible analysis of the disjunctions is as conjunctions of epistemic possibilities.

Though analyzed as conjunction, Cheyenne naa is not equivalent to English and. Cheyenne naa seems less specified than English and, with further specifications being contributed by the other particles in the complex connectives: naa máto (additive), naa nèhe'še (temporal), naa oha (contrastive), among others. In several 
cases, translations of naa with and were not appropriate (e.g., (27)). We saw an interesting overlap with the connectives in ASL and Walpiri, but also important differences. Much of the data came from texts, but the crucial came from semantic fieldwork, including negative data, about what is not possible.

Crosslinguistically, many languages build disjunction from conjunction. Mauri 2008 notes West Greenlandic =lu 'and', =luunniit 'or'; Hausa kuma, kokuma; and Dargi ya, yara. Arsenijević 2011 discusses Serbian/Croatian $i$ 'and' and ili 'or', where the disjunction is formed from the conjunction plus a question particle. The types of constructions used to express disjunction across languages involve conjunction, modality, questions, and additive particles. Studying these will hopefully lead us to a richer understanding of conjunction and disjunction in natural language and their connection to the logical operations.

\section{References}

Alonso-Ovalle, Luis. 2006. Disjunction in alternative semantics: University of Massachusetts, Amherst dissertation.

AnderBois, Scott. 2011. Issues and alternatives: University of California dissertation.

Arsenijević, Boban. 2011. Serbo-croatian coordinative conjunctions at the syntaxsemantics interface. The Linguistic Review doi:10.1515/tlir.2011.005.

Asher, Nicholas \& Laure Vieu. 2005. Subordinating and coordinating discourse relations. Lingua 115(4). 591-610. doi:10.1016/j.lingua.2003.09.017.

Bach, Kent. 1999. The myth of conventional implicature. Linguistics and Philosophy 22(4). 327-366.

Bar-Lev, Zev \& Arthur Palacas. 1980. Semantic command over pragmatic priority. Lingua 51. 137-146.

Biezma, María \& Kyle Rawlins. 2015. Alternative questions. Language and Linguistics Compass 9(11). 450-468. LNCO-0497.R3.

Bowler, Margit. 2014. Coordination and disjunction in a language without 'and'. In Semantics and Linguistic Theory (SALT) XXIV, 137-155.

Davidson, Kathryn. 2013. 'And' or 'or': General use coordination in ASL. Semantics and Pragmatics 6(4). 1-44. doi:10.3765/sp.6.4.

Deal, Amy Rose. 2011. Modals without scales. Language 87(3). 559-585. doi:10.1353/lan.2011.0060.

Fisher, Louise, Wayne Leman, Leroy Pine, Sr. \& Marie Sanchez. 2006. Cheyenne dictionary. Lame Deer, MT: Chief Dull Knife College. Also online: http: //www.cdkc.edu/cheyennedictionary/index.html.

Frege, Gottlob. 1892. über Sinn und Bedeutung. Zeitschrift für Philosophie und philosophische Kritik C. 25-50. Page references to reprint: Frege (1948). 
Complex connectives

Frege, Gottlob. 1948. On sense and reference. The Philosophical Review 57(3). 209-230.

Geurts, Bart. 2005. Entertaining alternatives: Disjunctions as modals. Natural Language Semantics 13. 383-410.

Grice, H. Paul. 1961. The causal theory of perception. Proceedings of the Aristotelian Society 35. 121-152.

Grice, H. Paul. 1975. Logic and conversation. In Peter Cole \& Jerry Morgan (eds.), Syntax and semantics 3: Speech acts, 64-75. New York: Academic Press.

Groenendijk, Jeroen \& Floris Roelofsen. 2009. Inquisitive semantics and pragmatics. In Jesus M. Larrazabal \& Larraitz Zubeldia (eds.), Meaning, content, and argument: Proceedings of the ILCLI international workshop on semantics, pragmatics, and rhetoric, 41-72. University of the Basque Country Publication Service.

Groenendijk, Jeroen \& Martin Stokhof. 1991. Dynamic predicate logic. Linguistics and Philosophy 14(1). 39-100. doi:10.1007/BF00628304.

Hobbs, Jerry R. 1985. On the coherence and structure of discourse. Tech. Rep. CSLI85-37 Center for the Study of Language and Information, Stanford University Stanford, California.

Inoue, Aya. 2007. From exclusive particle to adversative conjunction: A study on the particle tasol in Tok Pisin. Annual Meeting of the Berkeley Linguistics Society 33(1). 233-243. doi:10.3765/bls.v33i1.3530.

Kratzer, Angelika \& Junko Shimoyama. 2002. Indeterminate pronouns: The view from Japanese. In Yukio Otsu (ed.), The proceedings of the third tokyo conference on psycholinguistics, 1-25. Tokyo: Hituzi Syobo.

Lakoff, Robin. 1971. If's, and's, and but's about conjunction. In Charles J. Fillmore \& D. Terence Langendoen (eds.), Studies in linguistic semantics, 114-149. New York: Holt, Rinehart and Winston.

Lascarides, Alex \& Nicholas Asher. 1993. Temporal interpretation, discourse relations and commonsense entailment. Linguistics and Philosophy 16. 437493.

Leman, Wayne (ed.). 1980a. Cheyenne texts: An introduction to Cheyenne literature (Occasional Publications in Anthropology, Linguistics Series 6). Greeley, Colorado: Museum of Anthropology, University of Northern Colorado.

Leman, Wayne. 1980b. A reference grammar of the Cheyenne language (Occasional Publications in Anthropology, Linguistics Series 5). Greely, Colorado: Museum of Anthropology, University of Northern Colorado.

Leman, Wayne (ed.). 1987. Náévȧhóó'óhtséme / We are going back home: Cheyenne history and stories told by James Shoulderblade and others (Memoir 4). Winnipeg: Algonquian and Iroquoian Linguistics.

Leman, Wayne. 2011. A reference grammar of the Cheyenne language. Raleigh, 
North Carolina: Lulu Press. Updated version of Leman 1980b.

Malchukov, Andrej L. 2004. Towards a semantic typology of adversative and contrast marking. Journal of Semantics 21(2). 177-198. doi:10.1093/jos/21.2.177.

Matthewson, Lisa. 2004. On the methodology of semantic fieldwork. International Journal of American Linguistics 70(4). 369-415.

Matthewson, Lisa. 2014. Finding out what or does, by looking at languages without or. Talk given at the University of Pennsylvania, 7 March.

Mauri, Caterina. 2008. Coordination relations in the languages of europe and beyond. Mouton de Gruyter.

Murray, Sarah E. 2010. Evidentiality and the structure of speech acts: Rutgers University dissertation. http://www.semanticsarchive.net/Archive/WViOGQxY/.

Murray, Sarah E. 2016. Two imperatives in Cheyenne: Some preliminary distinctions. In Monica Macaulay, Margaret Noodin \& J. Randolph Valentine (eds.), Papers of the forty-fourth Algonquian conference (2012), 242-256. SUNY Press.

Murray, Sarah E. 2017. Cheyenne connectives. In Monica Macaulay, Margaret Noodin \& J. Randolph Valentine (eds.), Papers of the Forty-Fifth Algonquian Conference (2013), 149-162. Michigan State University Press.

Murray, Sarah E. \& William B. Starr. to appear. The structure of communicative acts. Linguistics \& Philosophy .

Potts, Christopher. 2005. The logic of conventional implicatures Oxford Studies in Theoretical Linguistics. Oxford: Oxford University Press.

Roberts, Craige. 1989. Modal subordination and pronominal anaphora in discourse. Linguistics and Philosophy 12(6). 683-721. doi:10.1007/BF00632602.

Romero, Maribel \& Chung-hye Han. 2003. Focus, ellipsis and the semantics of alternative questions. In Patricia Cabredo Hofherr Claire Beyssade, Olivier Bonami \& Francis Corblin (eds.), Empirical issues in syntax and semantics 4, 291-307. Presses Universitaires de Paris Sorbonne.

Rullmann, Hotze, Lisa Matthewson \& Henry Davis. 2005. Modals as distributive indefinites. Natural Language Semantics 16(4). 1-41. doi:10.1007/s11050008-9036-0.

Simons, Mandy. 1996. Disjunction and anaphora. In Teresa Galloway \& Justin Spence (eds.), Proceedings from semantics and linguistic theory VI, 245-260. Ithaca, NY: Cornell University.

Simons, Mandy. 2005a. Dividing things up: The semantics of or and the modal/or interaction. Natural Language Semantics 13(3). 271-316.

Simons, Mandy. 2005b. Semantics and pragmatics in the interpretation of or. In Efthymia Georgala \& Jonathan Howell (eds.), Proceedings from Semantics and Linguistic Theory XV, 205-222. Ithaca, NY: Cornell University.

Singh, Raj, Ken Wexler, Andrea Astle-Rahim, Deepthi Kamawar \& Danny Fox. 2016. Children interpret disjunction as conjunction: Consequences for theories 
Complex connectives

of implicature and child development. Natural Language Semantics 24(4). 305-352. doi:10.1007/s11050-016-9126-3.

Snider, Todd. 2017. Anaphoric reference to propositions: Cornell University dissertation.

Starr, William B. 2016. Conjoining imperatives and declaratives. In Proceedings from Sinn und Bedeutung 21, .

Stone, Matthew. 1997. The anaphoric parallel between modality and tense. Tech. Rep. 97-06 University of Pennsylvania Institute for Research in Cognitive Science.

Stone, Matthew. 1999. Reference to possible worlds. Tech. Rep. 49 Rutgers University Center for Cognitive Science. Update of Stone 1997.

Szabolsci, Anna \& Bill Haddican. 2004. Conjunction meets negation: A study in cross-linguistic variation. Journal of Semantics 21(3). 219-249.

Txurruka, Isabel Gómez. 2000. Philosophy of logic and natural language: Logical and natural connectives. In Xabier Arrozola, Bego na Carrascal, Kepa Korta \& Isabel Gómez Txurruka (eds.), Three papers on logic (communication, natural language connectives, many-valued modalities), 17-25. Donostia: Institute for Logic, Cognition, Language, and Information, University of the Basque Country.

Txurruka, Isabel Gómez. 2003. The natural language conjunction and. Linguistics and Philosophy 26. 255-285.

Williams, R. O. 1895. Only, - adversative. - misplacement of adverb. Modern Language Notes 10(3). 66-68.

Winter, Yoad. 1995. Syncategorematic conjunction and structured meanings. In Mandy Simons \& Teresa Galloway (eds.), Proceedings from semantics and linguistic theory V, 387-404. Ithaca, NY: CLC Publications.

Winter, Yoad \& Mori Rimon. 1994. Contrast and implication in natural language. Journal of Semantics 11(3). 365-406.

Zimmerman, Thomas Ede. 2000. Free choice disjunction and epistemic possibility. Natural Language Semantics 8(4). 255-290.

Sarah E. Murray

212 Morrill Hall

Department of Linguistics

Cornell University

Ithaca, NY 14853

sarah.murray@cornell.edu 